\title{
OUTCOMES OF TUBERCULOSIS TREATMENT DEPENDING ON CYP2C19 GENOTYPE
}

\section{P.B.Antonenko, V.I.Kresyun}

\author{
Odessa National Medical University
}

Key words: tuberculosis; CYP2C19; treatment outcome

\begin{abstract}
As proven earlier, in patients with tuberculosis (TB) the concentration of antituberculosis drugs like isoniazid and rifampicin may differ depending on polymorphism of CYP2C19. The aim of the research was to determine the peculiarities of the pulmonary TB course and its outcome after the in-patient treatment depending on CYP2C19 genotype of the patients. The analysis of medical cards from 83 patients with the primary pulmonary tuberculosis at the end of the in-patient treatment in Odessa regional TB dispensary was conducted in 2012 with consideration of CYP2C19 genotype. At the beginning of the treatment the processes of disintegration were 3 times less in patients with ${ }^{*} 1 /{ }^{*} 1$ genotype than in patients with ${ }^{*} 1 /{ }^{*} 2$ genotype $\left(10.3 \%\right.$ versus $\left.31.8 \% ; P<0.05 ; \chi^{2}=5.40\right)$, and 6.5 times less than in individuals with $* 2 /{ }^{*} 2$ genotype $(10.3 \%$ versus $\left.66.7 \% ; P<0.05 ; \chi^{2}=7.94\right)$. At the end of the in-patient treatment the signs of pulmonary destruction were 6.5 times more common in individuals with ${ }^{*} 1 /{ }^{*} 1$ genotype than in individuals with ${ }^{*} 1 /{ }^{*} 2$ genotype $\left(29.3\right.$ versus $\left.4.5 ; P<0.05 ; \chi^{2}=5.61\right)$. The signs of resorption and consolidation in the pulmonary tissue were observed in $74.1 \%$ of the patients with *1/*1 genotype, $95.5 \%$ of the patients with ${ }^{*} 1 /{ }^{*} 2$ genotype and $66.7 \%$ of the patients with ${ }^{*} 2 /{ }^{*} 2$ genotype. There were no significant differences between groups in relation to duration of the treatment and development of drug-resistance.
\end{abstract}

Today, tuberculosis (TB) or

1 "white plague" remains a major cause of death among infectious diseases in Ukraine. Despite certain positive changes, for example, reducing the TB incidence during the period of 2006-2011 from 83.2 to 67.2 per 100000 of the population $[5,8]$, it is still a high level of multidrug-resistant tuberculosis - from 7 to $25 \%$ of the primary resistance to $75 \%$ of the secondary resistance, and it significantly reduces the efficiency of treatment [2, 7].

It is known that the efficiency of treatment of numerous diseases, the severity of their course and their outcome largely depend on the genetic characteristics of a person, for example from polymorphism of genes of xenobiotics detoxification $[9,11]$. Among the last there is an important gene of cytochrome $\mathrm{P}_{450} 2 \mathrm{C} 19$ (CYP2C19), the expression of which is activated by anti-TB antibiotic rifampicin [6]. On the other hand, rifampicin can be a substrate for CYP2C19 and polymorphism of its gene may affect the metabolism of rifampicin and consequently the efficiency of TB treatment. In previous studies it has been shown that TB patients have higher frequency of the variant alleles $(* 2, * 3)$ than healthy people do, and it is also noted that polymorphism of CYP2C19 genotype in TB patients associated with differences of rifampicin and isoniazid concentrations $[1,2]$. So, the next step was to study the efficiency of treatment of TB-patients considering CYP2C19 genotype.

The aim of the research is to detect the peculiarities of the pulmonary TB course and the outcome after the in-patient treatment depending on CYP2C19 genotype of the patients.

\section{Materials and Methods}

The analysis of medical cards from 83 patients with the primary pulmonary tuberculosis at the end of the in-patient treatment in Odessa regional TB dispensary was conducted in 2012. Among the enrolled patients 39 of them (47.0\%) were women, others - 44 (53.0\%) were men. The age varied from 18 to 73 years old (average - 35.9 years old). All TB patients received the same standard therapy according to the Order of Ministry of Public Health No. 384 from 9.06.2006 regardless of CYP2C19 genotype [4].

P.B.Antonenko - Candidate of Medicine (PhD), associate professor of the Department of General and Clinical Pharmacology of the Odessa National Medical University

We considered medical diagnosis at the beginning and at the end of in-patients treatment, including TB-form, characteristics of TB-lesions, bacterial excretion, etc.

At the beginning of the treatment provided CYP2C19 genotype in TB-patients was detected. The DNA material was extracted from the blood of donors using a DNA sorbB kit (AmpliSens, Russian Federation). CYP2C19 genotype was detected with the help of the polymerase chain reaction (PCR) and endonuclease analysis according to J. A. Goldstein, J. Blaisdell, 2004 [10]. For PCR amplification of CYP2C19*2 and CYP2C19*3 alleles two pairs of relevant specific primers were used. PCR products of CYP2C19*2 and CYP2C19*3 were exposed to the action of restriction enzymes (restrictases) SmaI i BamH1, respectively. As the restriction was absent in the mutant alleles, PCR products avoided digestion by the corresponding restrictase enzymes. Processing of the statistical data obtained was performed using Microsoft Excel and "Primer Biostatistica" programmes.

\section{Results and Discussion}

In accordance with the genotype of CYP2C19 approximately $69.9 \%$ of TB-patients were carri- 
Table 1

\section{Characteristics of tuberculosis processes depending on CYP2C19 genotype}

\begin{tabular}{|c|c|c|c|c|c|c|c|}
\hline \multirow{2}{*}{\multicolumn{2}{|c|}{$\begin{array}{l}\text { Characteristics } \\
\text { of TB-processes }\end{array}$}} & \multicolumn{3}{|c|}{ At the beginning of the treatment, $(\%)$} & \multicolumn{3}{|c|}{ At the end of the in-patient treatment, (\%) } \\
\hline & & ${ }^{*} 1 / * 1, \mathrm{n}=58$ & ${ }^{*} 1 /{ }^{*} 2, \mathrm{n}=22$ & ${ }^{*} 2 /{ }^{*} 2, \mathrm{n}=3$ & ${ }^{*} 1 /{ }^{*} 1, \mathrm{n}=58$ & ${ }^{*} 1 /{ }^{*} 2, n=22$ & $* 2 /{ }^{*} 2, n=3$ \\
\hline \multirow{2}{*}{ Spreading } & bilateral & $23(39.7)$ & $7(31.8)$ & 2 (66.7) & $23(39.7)$ & $6(27.3)$ & 2 (66.7) \\
\hline & unilateral & $35(60.3)$ & $15(68.2)$ & $1(33.3)$ & $35(60.3)$ & $16(72.7)$ & $1(33.3)$ \\
\hline \multirow{2}{*}{ Destruction } & yes & $22(37.9)$ & $11(50.0)$ & $3 *(100)$ & $17(29.3)$ & $1 * \#(4.5)$ & $1(33.3)$ \\
\hline & no & $36(62.1)$ & $11(50.0)$ & 0 & $41(70.7)$ & $21(95.5)$ & $2(66.7)$ \\
\hline \multirow{4}{*}{$\begin{array}{l}\text { Stage of the } \\
\text { TB-process }\end{array}$} & infiltration & $35(60.3)$ & $8(36.4)$ & $0^{*}$ & 6\# (10.3) & $1 \#(4.5)$ & $1(33,3)$ \\
\hline & disintegration & $6(10.3)$ & $7 *(31.8)$ & $2 *(66.7)$ & $9(15.5)$ & $0 * \#$ & 0 \\
\hline & dissemination & $17(29.3)$ & $7(31.8)$ & $1(33.3)$ & 0\# & 0\# & 0 \\
\hline & resorption & 0 & 0 & 0 & 43\# (74.1) & 21\# (95.5) & 2 (66.7) \\
\hline \multirow{4}{*}{$\begin{array}{l}\text { Category } \\
\text { of patients }\end{array}$} & 1 & $39(67.2)$ & $19(86.4)$ & $3(100)$ & $38(65.5)$ & $16(72.7)$ & 2 (66.7) \\
\hline & 2 & $6(10.3)$ & $1(4.5)$ & 0 & $3(5.2)$ & $1(4.5)$ & 0 \\
\hline & 3 & $12(20.7)$ & $2(9.1)$ & 0 & $6(10.3)$ & $1(4.5)$ & 0 \\
\hline & 4 & $1(1.7)$ & 0 & 0 & 11\# (19.0) & 4\# (18.2) & $1(33.3)$ \\
\hline $\begin{array}{l}\text { Multidrug } \\
\text { resistance }\end{array}$ & & $1(1.7)$ & 0 & 0 & $11(19.0)$ & $4(18.2)$ & $1(33.3)$ \\
\hline
\end{tabular}

Notes:

1) \# $-\mathrm{P}<0.05$ (in relation to the initial level of the corresponding group);

$2{ }^{*}-P<0.05$ (in relation to the patients with ${ }^{*} 1{ }^{*} 1$ genotype).

ers of the homozygous wild type of the gene ${ }^{*} 1 /{ }^{*} 1,26.5 \%$ - carriers of the heterozygous genotype $* 1 / 2$, and finally, $3.6 \%$ - carriers of the variant (mutated) genotype $-* 2 / 22$. For convenience it is possible to attribute the persons with ${ }^{*} 1 /{ }^{*} 1$ genotype to rapid metabolizers (RM), persons with ${ }^{*} 1 /{ }^{*} 2$ genotype to intermediate metabolizers (IM) and persons with $* 2 /{ }^{*} 2$ genotype to slow metabolizers (SM).

At the beginning of the treatment in the in-patient department the destruction processes in lungs were observed approximately in one third of RM (37.9\%), in half of IM and in all SM. Thus, one could see the processes of destruction in patients with ${ }^{*} 1 /{ }^{*} 1$ genotype almost three times more often than in patients with $* 2 /{ }^{*} 2$ genotype $\left(\mathrm{P}<0.05 ; \chi^{2}=4.54\right.$ at a critical value here and after 3.84) (Table 1).

Approximately one third of RM and IM had a bilateral pulmonary $\mathrm{TB}$, about $66.7 \%$ of SM had a bilateral process as well. The disseminative pulmonary TB was observed almost in one third of genotype ${ }^{*} 1 /{ }^{*} 1$ carriers $(29.3 \%)$, in two-third of genotype $* 2 / * 2$ car- riers and only in $13.6 \%$ individuals with ${ }^{*} 1 /{ }^{*} 1$ genotype.

In the majority of RM and IM an infiltrative TB was observed, in addition in IM it was 1.5 times more often than in RM (86.4\% versus $58.6 \%, \mathrm{P}<0.05 ; \chi^{2}=5.49$ ) (Fig. 1 ). A focal pulmonary TB was detected only in $12.1 \%$ of RM and it was completely absent in IM and SM.

Among the RM processes disintegration and dissemination in lungs occurred in 10.3 and 29.3\%, respectively (Table 1). At the same time among IM these processes were observed in $31.8 \%$ of the patients, among SM - in $66.7 \%$ and $33.3 \%$, respectively. Thus, among the patients with ${ }^{*} 1 /{ }^{*} 1$ genotype the processes of disintegration were 3 times less than in the patients with ${ }^{*} 1 /{ }^{*} 2$ genotype $\left(\mathrm{P}<0.05 ; \chi^{2}=\right.$ $=5.40$ ), and 6.5 times less than in individuals with $* 2 /{ }^{*} 2$ genotype $\left(\mathrm{P}<0.05 ; \chi^{2}=7.94\right)$. Meanwhile, the processes of the pulmonary tissues infiltration occurred more often in RM - 60.3\%, almost twice as less in IM - 36.4\% ( $>0.05)$. On the contrary, the processes of infiltration were completely absent in SM $\left(\mathrm{P}<0.05 ; \chi^{2}=4.25\right)$.
At the beginning of the in-patient treatment regardless of the genotype and according to the microscopy approximately half of the patients with genotype $* 1 /{ }^{*} 1$ and ${ }^{*} 1 /{ }^{*} 2(46.6 \%$ and $50.0 \%$, respectively) and two-thirds of the individuals with genotype $* 2 /{ }^{*} 2$ were smear-positive (Fig. 2). According to the cultural method the majority of patients $-62.5 \%$ of RM, $59.1 \%$ of IM and $66.7 \%$ of SM were smear-positive. The vast majority of the patients with the genotype of RM, IM or SM belonged to I (primary pulmonary tuberculosis) or III category (smear-negative primary tuberculosis) - 87.9\%; $95.5 \%$ and $100 \%$, respectively. Thus, at the beginning of the treatment the patients with genotype ${ }^{*} 1 /{ }^{*} 1$ had manifestations of disintegration and destruction in pulmonary tissues more often than carriers of $* 1 /{ }^{*} 2$ or $* 2 /{ }^{*} 2$ genotype.

Duration of the in-patient treatment was the longest in the individuals with ${ }^{*} 1 /{ }^{*} 1$ genotype $93.6 \pm 3.3$ days. In the patients with $* 1 /{ }^{*} 2$ or $* 2 /{ }^{*} 2$ it was shorter $86.8 \pm 2.7$ days or $86.5 \pm 7.8$ days, respectively. 


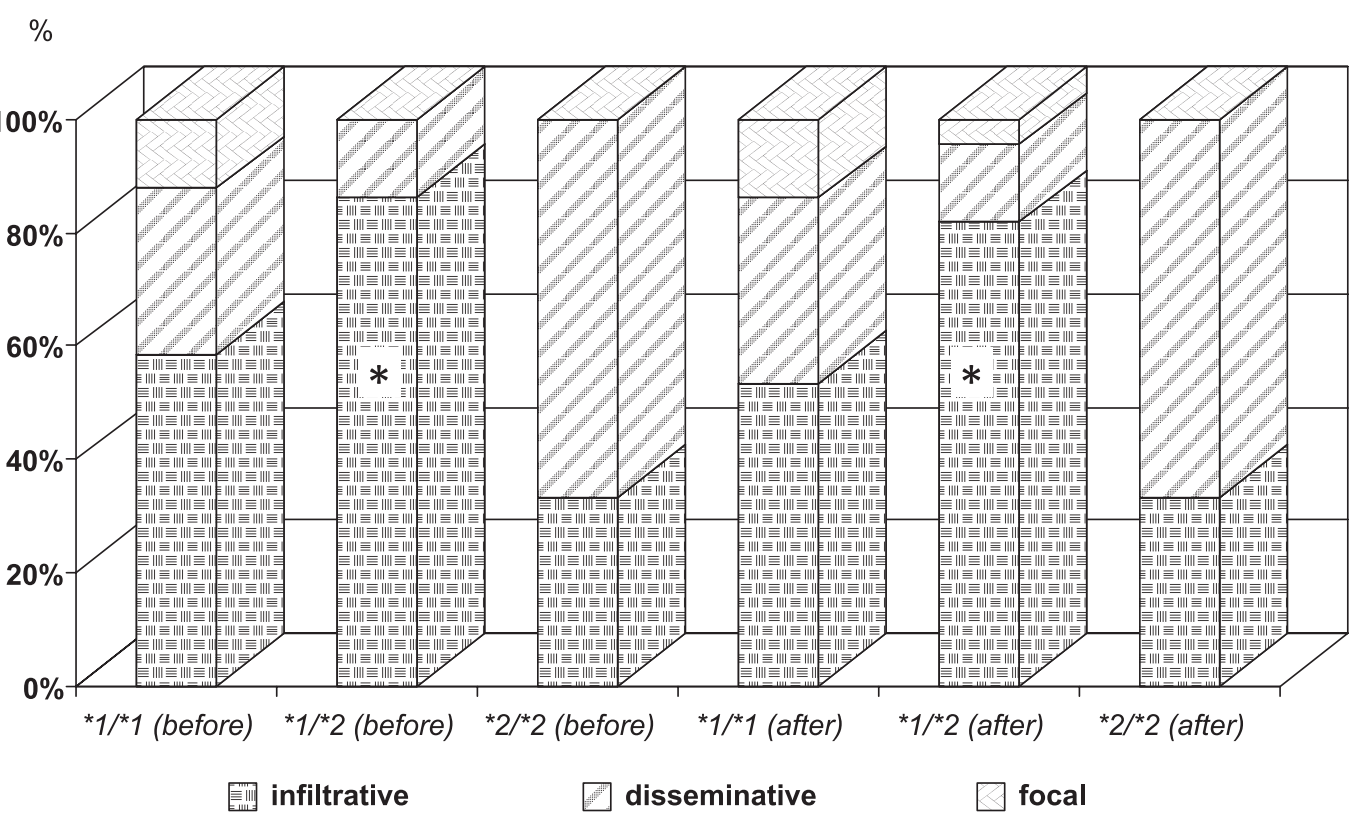

Fig. 1. Forms of the pulmonary TB taken into consideration CYP2C19 genotype at the beginning (before) and at the end (after) of the in-patient treatment Note: ${ }^{*}$ - $<0.05$ (in relation to the patients with ${ }^{*} 1 /{ }^{*} 1$ genotype).

At the end of the in-patient treatment the processes of destruction remained in $29.3 \%$ of RM and one-third of SM (Table 1). At the same time in IM the processes mentioned above were in $4.5 \%$. Thus, the signs of pulmonary destruction were 6.5 times more in the individuals with ${ }^{*} 1 /{ }^{*} 1$ genotype than in the individuals with ${ }^{*} 1 /{ }^{*} 2$ genotype $\left(\mathrm{P}<0.05 ; \chi^{2}=\right.$ $=5.61)$. In all groups as the result of the treatment provided there was reduction of the number of patients with the symptoms of destruction, particularly in IM $(\mathrm{P}<0.05$; $\chi^{2}=11.46$ ) (Table 2). Termination of destruction was observed in $27.3 \%$ of the persons with $* 1 /{ }^{*} 1$ genotype, in two-thirds of $* 2 / * 2$ genotype carriers and in $90.9 \%$ of the individuals with ${ }^{*} 1 / 2$ genotype. Thus, conversion of the pulmonary destruction in IM occured 3.3 times more often $\left(\mathrm{P}<0.05 ; \chi^{2}=\right.$ $=11.89$ ) than in RM, and it took about 60 days on an average.

At the end, as well as at the beginning of the in-patient treatment, in majority of RM and IM (53.4\% and $81.8 \%$, respectively) infiltrative tuberculosis was observed (Fig. 1). Thus, at the end of the treatment provided an infiltrative TB occurred in IM 1.5 times more often than in RM $(\mathrm{P}<0.05$; $\left.\chi^{2}=5.41\right)$. At the same time the twothird of SM had a disseminating form of pulmonary TB.

As a result of the treatment conducted, the number of RM and IM with tuberculosis infiltration decreased by 5.6 times $\left(\mathrm{P}<0.05 \chi^{2}=\right.$ $=31.73)$ and by 8.1 times $(\mathrm{P}<0.05$; $\left.\chi^{2}=6,84\right)$, respectively; further spreading (contamination) of TB in lungs stopped $\left(\mathrm{P}<0.05 ; \chi^{2}=19.92\right.$ and $\chi^{2}=8.32$, respectively) (Table 1 ).
In IM at the end of the in-patient treatment the further spreading (contamination) of TB in lungs was terminated, and the difference was significant in relation to the baseline, as well as in relation to the RM stationary treatment ceased phenomenon of disintegration, and the difference was statistically significant in relation to the baseline $\left(\mathrm{P}<0.05 ; \chi^{2}=8.32\right)$ and $\mathrm{RM}$ $\left(\mathrm{P}<0.05 ; \chi^{2}=3.85\right)$. At the same time the signs of resorption and con-

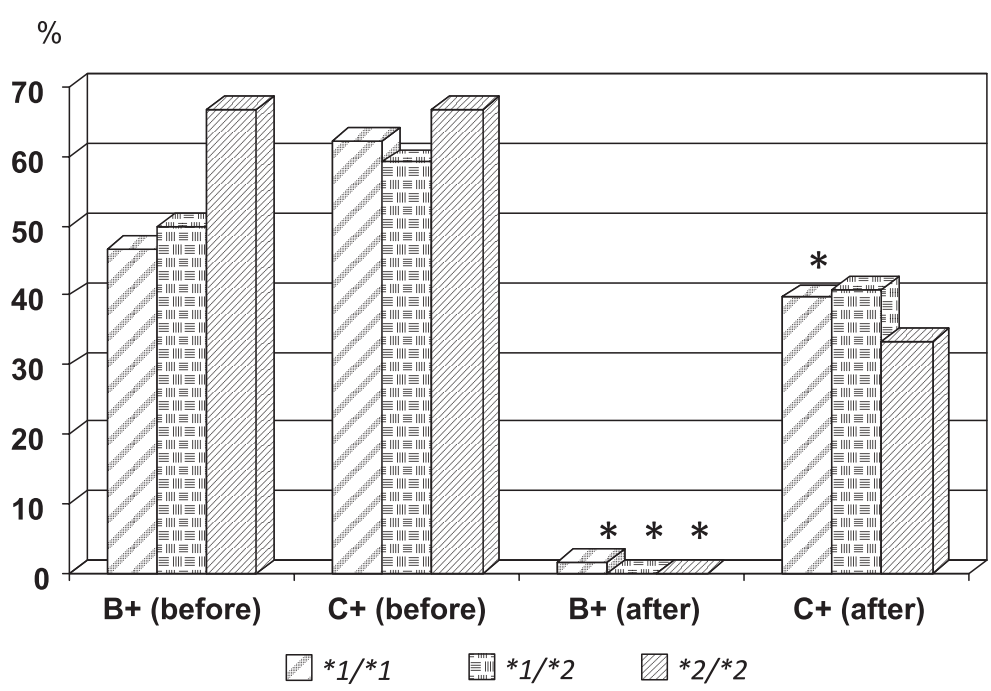

Fig. 2. The number of patients with different CYP2C 19 genotype that were smear- positive according to bacterioscopy $(B+)$ or the culture method $(\mathrm{C}+$ ) at the beginning (before) and at the end (after) of the in-patient treatment Note: * $-\mathrm{P}<0.05$ in relation to the initial level of the corresponding group. 
Conversion of destruction and positive smears depending on CYP2C19 genotype

\begin{tabular}{|c|c|c|c|c|c|c|}
\hline \multirow{3}{*}{$\begin{array}{l}\text { Genotype } \\
\text { of patients }\end{array}$} & \multirow{2}{*}{\multicolumn{2}{|c|}{ Conversion of destruction }} & \multicolumn{4}{|c|}{ Conversion of positive smears according to } \\
\hline & & & \multicolumn{2}{|c|}{ bacterioscopy } & \multicolumn{2}{|c|}{ culture } \\
\hline & $\begin{array}{l}\text { number of } \\
\text { patients (\%) }\end{array}$ & $\begin{array}{c}\text { duration (days) } \\
\pm \text { SEM }\end{array}$ & $\begin{array}{l}\text { number of } \\
\text { patients (\%) }\end{array}$ & $\begin{array}{c}\text { duration (days) } \\
\pm \text { SEM }\end{array}$ & $\begin{array}{c}\text { number of } \\
\text { patients (\%) }\end{array}$ & $\begin{array}{c}\text { duration (days) } \\
\pm \text { SEM }\end{array}$ \\
\hline$* 1 / * 1$ & $6 / 22(27.3)$ & $59.7 \pm 2.3$ & $26 / 27(96.3)$ & $58.7 \pm 1.2$ & $13 / 36(36.1)$ & $69.0 \pm 3.3$ \\
\hline$* 1 / * 2$ & $10 / 11 *(90.9)$ & $63.7 \pm 2.8$ & $11 / 11(100)$ & $57.6 \pm 2.1$ & $5 / 13(38.5)$ & $68.6 \pm 3.0$ \\
\hline$* 2 / * 2$ & $2 / 3(66.7)$ & $58.2 \pm 5.6$ & $2 / 3(66.7)$ & $47.5 \pm 10.1^{*}$ & $1 / 2(50.0)$ & 87 \\
\hline
\end{tabular}

Note: ${ }^{*}-\mathrm{P}<0.05$ (in relation to the patients with ${ }^{*} 1 /{ }^{*} 1$ genotype).

solidation in the pulmonary tissue were observed in $74.1 \%$ of RM, 95.5\% of IM $\left(\mathrm{P}<0.05 ; \chi^{2}=68.33\right.$ and $\chi^{2}=40.17$, respectively) and in $66.7 \%$ of SM.

Regardless of the genotype the percentage of patients with bi- and unilateral TB-lesions of the lungs almost did not change during the in-patient treatment. During the treatment conducted the number of patients with genotype ${ }^{*} 1 /{ }^{*} 1$, ${ }^{*} 1 /{ }^{*} 2$ and $* 2 / * 2$ belonging to category 4 increase up approximately equally - by $17.3 \%\left(\mathrm{P}<0.05 ; \chi^{2}=\right.$ =9.29), 18.2\% $\left(\mathrm{P}<0.05 ; \chi^{2}=4.40\right)$ and $33.3 \%(\mathrm{P}>0.05)$, respectively. The number of multidrug resistant TB cases in the first and second groups was also almost the same $-19.0 \%$ and $18.2 \%$, respectively.

According to bacterioscopy all SM and IM, as well as $98.3 \%$ of RM at the time of discharge from the hospital were smear-negative (Fig. 2). In addition, smear conversion was in $96.3 \%$ and $66.7 \%$ of SM and RM, respectively, and in $100 \%$ of IM. It took 58 days for conversion of positive smears for RM and IM and 47.5 days for SM, therefore, it was 1.2 times faster than in $\mathrm{RM}(\mathrm{P}=0.020$; CI=1.91 ...20.49) (Table 2).
According to the data of the culture method at the end of the in-patient treatment $40 \%$ of the individuals with $* 1 /{ }^{*} 1$ and $* 1 /{ }^{*} 2$ genotype, as well as one-third of the individuals with $* 2 /{ }^{*} 2$ genotype remained smear-positive (Fig. 2). As a result of the treatment, the number of smear-positive patients with *1/*1 genotype decreased by almost 1.5 times $\left(\mathrm{P}<0.05 ; \chi^{2}=5.83\right)$. The smear conversion observed had almost the same speed in RM and IM - within 69 days (Table 2).

The data obtained have proven that at the beginning of treatment the signs of destruction, infiltration and disintegration were more common in the patients with genotype CYP2C19*1/*1 than in patients with $C Y P 2 C 19^{*} 1 /^{*} 2$ or CYP2C19*2/*2 genotypes. At the end of the in-patient treatment the processes of resorption and abortion of destruction were more often associated with ${ }^{*} 1 /{ }^{*} 2$ genotype. According to the preliminary data the genotype - ${ }^{*} 1 /{ }^{*} 2$ mentioned below was associated with a high concentration of isoniazid and a slightly lower concentration of rifampicin in the blood during the treatment [8]. On the other hand, the patients with genoty- pes ${ }^{*} 1 /{ }^{*} 1$ or ${ }^{*} 1 /{ }^{*} 2$ had approximately the same duration of the in-patient treatment and the percentage of positive smears at the beginning and at the end of the treatment provided and the same number of the developed cases of drug-resistant tuberculosis. Unfortunately, it was difficult to assess the impact of the presence of genotype $* 2 /{ }^{*} 2$ on the tuberculosis process due to the small number of such patients.

\section{CONCLUSIONS}

1. At the beginning of the treatment the patients with genotype ${ }^{*} 1 /{ }^{*} 1$ had manifestations of disintegration and destruction in pulmonary tissues more often than carriers of ${ }^{*} 1 /{ }^{*} 2$ or $* 2 /{ }^{*} 2$ genotype.

2 . At the end of in-patient treatment the processes of resorption and abortion of destruction were more often associated with $* 1 /{ }^{*} 2$ than $* 1 /{ }^{*} 1$ genotype.

3 . The patients with $*^{*} /{ }^{*} 1$ or *1/*2 genotypes had approximately the same duration of the in-patient treatment and the percentage of positive smears at the beginning and at the end of the treatment provided and the same number of the developed cases of drugresistant tuberculosis.

\section{REFERENCES}

1. Антоненко П.Б., Кресюн В.Й. // Вісник наукових досліджень. - 2013. - №2. - С. 32-35.

2. Антоненко П.Б., Кресюн В.Й. // Одеський мед. журн. - 2013. - №5. - С. 16-20.

3. Мельник В.М., Новожилова І.О., Матусевич В.Г. та ін. // Укр. пульмонол. журн. - 2012. - №1. C. 5-7.

4. Наказ МОз України №384 від 09.06.2006 р. «Про затвердження протоколу надання медичної допомоги хворим на туберкульоз»: Нормативні директивні правові документи. - К., 2006. - 87 с. 
5. Фещенко Ю.І., Мельник В.М., Матусевич В.Г. та ін. // Укр. пульмонол. журн. - 2011. - №4. - С. 5-10.

6. Bertram G. Katzung's Basic and Clinical Pharmacology. 12 ${ }^{\text {th }}$ Ed. - McGraw-Hill Education, 2012. - P. 842.

7. Dymova M.A., Liashenko O.O., Poteiko P.I. et al. // BMC Infect. Dis. - 2011. - №11. - P. 77 (http://www. biomedcentral.com/1471-2334/11/77).

8. Falzon D., Jaramillo E., Schünemann H.J., Arentz M. // Eur. Respir. J. - 2011. - Vol. 38, №3. - P. 516-528.

9. Geetha Ramachandran, Soumya Swaminathan // Pharmacogenomics and Personalized Medicine. 2012. - №5. - P. 89-98.

10. Goldstein J.A., Blaisdell J. // Methods Enzymol. - 1996. - Vol. 272. - P. 210-218.

11. Mde J. Castillejos-López, García-Sancho M.C., Quiñones-Falconi F., Pérez-Padilla J.R. // Rev. Invest. Clin. 2008. - Vol. 60, №1. - P. 47-57.

\section{НАСЛІДКИ ЛІКУВАННЯ ТУБЕРКУЛЬОЗУ ЛЕГЕНЬ ЗАЛЕЖНО ВІД ГЕНОТИПУ СУР2С19 \\ П.Б.Антоненко, В.Й.Кресюн \\ Одеський національний медччний університет \\ Ключові слова: туберкульоз; СРР2С19; наслідки лікування}

У попередніх дослідженнях було показано, що поліморфізм гена СҮР2С19 у хворих на туберкульоз (ТБ) асоціювався з відмінностями у концентраціях рифампіцину та ізоніазиду в крові хворих. Метою дослідження було визначення особливостей перебігу та наслідків лікування туберкульозу легень на стаціонарному етапі в залежності від генотипу СYР2C19. Було проведено аналіз медичних карт 83 хворих на вперше діагностований туберкульоз легенів наприкінці стаціонарного лікування в Одеському обласному протитуберкульозному диспансері в 2012 р. з урахуванням генотипу СҮР2C19. На початку лікування у хворих, які мали генотип *1/*1, процеси розпаду спостерігались у 3 рази рідше, ніж у хворих з генотипом *1/*2 (10.3\% проти 31.8\%; $\left.P<0.05 ; \chi^{2}=5.40\right)$ i в 6,5 разів рідше, ніж у хворих з генотипом *2/*2 (10.3\% versus 66.7\%; $\left.P<0.05 ; \chi^{2}=7.94\right)$. Наприкінці стаціонарного лікування ознаки деструкцї легеневої тканини спостерігались у 6.5 разів частіше за носіїв генотипу *1/*1, ніж у осіб з генотипом *1/*2 (29.3 versus 4.5; P<0.05; $\left.\chi^{2}=5.61\right)$. Ознаки розсмоктування і ущільнення легеневої тканини відзначались у $74.1 \%$ осіб з генотипом *1/*1, у 95.5\% осіб з генотипом *1/*2 і 66.7\% осіб з генотипом *2/*2. Вірогідна різниця між групами щодо тривалості стаціонарного лікування та розвитку хіміорезистентного туберкульозу була відсутня.

\section{ИСХОД ЛЕЧЕНИЯ ТУБЕРКУЛЕЗА ЛЕГКИХ В ЗАВИСИМОСТИ ОТ ГЕНОТИПА СҮР2С19 \\ П.Б.Антоненко, В.И.Кресюн}

Одесский национальный медицинский университет

Ключевые слова: туберкулез; СҮР2С19; исход лечения

В предыдущих исследованиях было продемонстрировано, что полиморфизм гена СҮР2С19 у больных туберкулезом (ТБ) ассоциировался с отличиями концентраций рифампицина и изониазида в крови больных. Целью исследования было определение особенностей течения и исходов лечения туберкулеза легких на стационарном этапе в зависимости от генотипа СҮР2С19. Был проведен анализ медицинских карт 83 больных с впервые диагностированным туберкулезом легких при завершении стационарного лечения в Одесском областном противотуберкулезном диспансере в 2012 г. с учетом генотипа СҮР2С19. В начале лечения у больных, имевших генотип *1/*1, процессы распада наблюдались в 3 раза реже, чем у больных с генотипом *1/*2 (10.3\% против $31.8 \%$; $\left.P<0.05 ; \chi^{2}=5.40\right)$ и в 6,5 раз реже, чем у больных с генотипом ${ }^{*} 2 /{ }^{*} 2\left(10.3 \%\right.$ против $\left.66.7 \% ; P<0.05 ; \chi^{2}=7.94\right)$. В конце стационарного лечения признаки деструкции легочной ткани наблюдались в 6.5 раз чаще у носителей генотипа *1/*1, чем у лиц с генотипом *1/*2 (29.3 против 4.5; $\left.P<0.05 ; \chi^{2}=5.61\right)$. Признаки рассасывания и уплотнения легочной ткани отмечались у $74.1 \%$ пациентов с генотипом $* 1 /{ }^{*} 1$, у $95.5 \%$ лиц с генотипом * $1 /{ }^{*} 2$ и $66.7 \%$ лиц с генотипом *2/*2. Достоверная разница между группами относительно длительности стационарного лечения и развития химиорезистентного туберкулеза отсутствовала.

Address for correspondence:

Received in 11.03.2014

2, Valikhovsky lane, Odessa, 65082, Ukraine.

Tel. (48) 717-35-45. E-mail: peterantonenko@yandex.ru.

Odessa National Medical University 